\title{
Dansk universitetspædagogik frem i lyset
}

\author{
Kim Jesper Herrmann, Center for Undervisning og Læring, Aarhus Universitet, \\ ansvarshavende redaktør for Dansk Universitetspædagogisk Tidsskrift.
}

Den 24. november 2014 barslede Kvalitetsudvalget med rapporten Høje mål - fremragende undervisning i videregående uddannelser. Den omfattende rapport på 174 sider og flere hundrede siders bilag sammenfattes i otte overordnede anbefalinger, der vedrører så forskellige emner som studieintensitet, regulering og ansvarsplacering, relevans og kvalitet, censorinstitution og optagelsessystem. Det er endnu uvist, hvorvidt anbefalingerne vil udmønte sig i konkret regulering og lovgivning, men sikkert er det, at rapporten kommer til at sætte dagsordenen for offentlig debat og politisk beslutningstagning de næste år frem.

Fra et universitetspædagogisk synspunkt er valget af teori- og analyseramme interessant. Udvalget har valgt den amerikanske 'student engagement'-litteratur som teoretisk ramme, og empirisk danner de amerikanske spørgeskemaer NSSE og FSSE afsæt for dataindsamlingen blandt danske undervisere og studerende. Til gengæld har udvalget - når man ser bort fra en række cases fra danske videregående uddannelser - kun i begrænset grad fundet inspiration i dansk universitetspædagogisk forskning. På rapportens side 44 begrundes valget af fortrinsvis amerikansk forskning med, at der nok findes dansk universitetspædagogisk forskning, men at "[i] modsætning til den omfattende internationale litteratur er omfanget af systematisk, tværgående viden og data om de videregående uddannelser i dansk kontekst relativt sparsom." (Kvalitetsudvalget, 2014:44).

Hvad enten man er enig i sidstnævnte vurdering eller ej: Udvalgets sparsomme anvendelse af dansk forskning i universitetspædagogik er en kærkommen anledning til at reflektere over, hvad der er Dansk Universitetspædagogisk Tidsskrifts rolle, og ikke mindst, hvad der skal til for at fremme kendskabet til dansk universitetspædagogisk forskning og praksis. 


\section{Målgrupper og formål}

Formålet med Dansk Universitetspædagogisk Tidskrift er at være publiceringskanal for dansk universitetspædagogisk forskning og praksis, og tidsskriftets raison d'être kan sammenfattes i fire hovedpunkter:

i. at henvende sig til undervisere med henblik på at fremme studenterrettet undervisning på danske universiteter,

ii. at henvende sig til universitetspædagogiske forskere med henblik på fortsat udvikling af forskningsfeltets teori, empiri og metode,

iii. at henvende sig til undervisningsudviklere for bedst muligt at støtte varetagelsen af pædagogisk kompetenceudvikling på danske universiteter, og endelig,

iv. at henvende sig til ledere og beslutningstagere med henblik på at sikre, at beslutninger af betydning for varetagelse af uddannelse på danske universiteter træffes på det bedst mulige grundlag, teoretisk såvel som empirisk.

\section{Forskning og politik}

Politiske beslutninger, uanset om de træffes i Folketinget, ministerier, universitetsledelser, dekanater eller studienævn, er influeret af aktørernes interesser og virkelighedsopfattelser. Hvordan aktørerne mener verden er, og hvordan aktørerne mener verden bør være. Det er ikke forskningens opgave at træffe politiske eller normative valg (Weber, 2000), og det er derfor heller ikke DUT's opgave at agere politisk. Dette betyder dog ikke, at universitetspædagogiske forskere og praktikere skal afholde sig fra at undersøge, diskutere og forholde sig kritisk og konstruktivt til politiske beslutninger og grundlaget for disse.

Et eksempel: Kvalitetsudvalget anbefaler, at man systematisk indsamler data om uddannelsernes kvalitet og relevans, fx ved at gennemføre tilbagevendende spørgeskemaundersøgelser blandt studerende og helst ved brug af spørgeskemaer, som kan sammenlignes med udenlandske (i dette tilfælde amerikanske) skemaer. Præmisserne for anbefalingen er altså, at universitetsuddannelser bør være (erhvervs)relevante, at studerende er i stand til at bedømme, om dette er tilfældet, og at det er meningsfuldt at sammenligne overordnede målsætninger for henholdsvis de amerikanske og de danske systemer for videregående uddannelse. Sådanne præmisser kan og bør dansk universitetspædagogisk forskning undersøge, diskutere og forholde sig kritisk og konstruktivt til. Derfor er det også en skam, at dansk universitetspædagogisk forskning ikke i højere grad er lagt til grund for konklusionerne i Kvalitetsudvalgets nyeste rapport. 


\section{Fremme kendskabet til feltet}

Når dette er sagt, er der alligevel grund til at glædes over rapporten og det, vi kan lære af den.

For det første er der grund til at glæde sig over, at rapporten sætter fokus på helt centrale emner så som i) sikring af nødvendige beføjelser og ansvar til studieledere, ii) en formel og reel sidestilling af undervisnings- og forskningskompetencer ved ansættelser, iii) et større fokus på de studerendes læring og engagement i studierne, iv) et større fokus på at tilrettelægge undervisning, som motiverer de studerende til at engagere sig i deres studier, fx gennem en øget grad af underviserkontakt, feedback og brug af IT i undervisningen. Alt sammen emner, som har stor universitetspædagogisk relevans og interesse.

For det andet er rapporten en oplagt kilde for de næste mange års universitetspædagogiske forskning. For bare at nævne nogle få eksempler på mulige forskningsspørgsmål: Er der belæg for at antage en sammenhæng mellem læringsudbytte og tid brugt på studier? Hvad må antages at være konsekvensen, hvis anbefalingen om at ophæve kravet om ekstern censur ved en tredjedel af eksaminerne ophæves? Hvor valide er resultaterne af de amerikanske NSSE FSSE i en dansk kontekst? Hvordan ser danske undervisere og studieledere på de såkaldte 'graduate attributes', dvs. de færdige kandidaters kompetencer? Er det overhovedet muligt at udvikle valide indikatorer på kvalitet i uddannelserne, og hvilke afledte konsekvenser (positive som negative) kan forventes, hvis man indfører en systematisk monitorering af disse? I det hele taget bygger Kvalitetsudvalgets rapport på en række forudsætninger, som det vil være interessant at få efterprøvet og diskuteret ud fra universitetspædagogisk teori og empiri.

For det tredje er rapporten en vigtig påmindelse om, at publicering i et videnskabeligt tidsskrift er en nødvendig men ikke tilstrækkelig forudsætning for at sikre den fornødne opmærksomhed på den nyeste viden om dansk universitetspædagogik. Selve publiceringen $i$ et videnskabeligt tidsskrift sikrer arbejdet en videnskabelig legitimitet og kvalitet i og med, at det har gennemgået en fagfællebedømmelse, men hvad angår selve formidlingen af forskningen, er der flere kanaler til rådighed. Lad der derfor lyde en stærk opfordring til at dele egne og kollegers forskning og praksisbeskrivelser. Gennem mails til centralt placerede beslutningstagere, gennem kronikker og analyser i landsdækkende aviser, gennem interview med interesserede journalister, gennem opdateringer og links på de sociale medier.

Dansk universitetspædagogik har fortjent at komme frem i lyset. Lad os hjælpe hinanden med at skabe og formidle forskning af høj kvalitet, der vedrører aktuelle problemstillinger inden for dansk universitetspædagogik.

God skrivelyst. 


\section{Litteratur}

Udvalg for Kvalitet og Relevans i de Videregående Uddannelser ("Kvalitetsudvalget"). (2014). Høje mål - fremragende undervisning i videregående uddannelser. Analyserapport. Kan hentes på www.ufm.dk/kvalitetsudvalget.

Weber, M. (2000). "Samfundsvitenskapenes «objektivitet»". I: M. Weber ([1922] 2000): Makt og byråkrati : essays om politikk og klasse, samfunnsforskning og verdier; utvalg og innledning ved Egil Fivelstad; oversatt av Dag Østerberg. Oslo. Gyldendal Norsk Forlag. 